\title{
Nasal Cavity and Paranasal Sinus Small Cell Carcinoma
}

National Cancer Institute

\section{Source}

National Cancer Institute. Nasal Cavity and Paranasal Sinus Small Cell Carcinoma. NCI

Thesaurus. Code C116318.

A very rare small cell carcinoma that arises from the nose and paranasal sinuses. 